\title{
Perancangan Komik Fotografis Berbasis Website sebagai Media Promosi Pariwisata Kabupaten Banyuwangi
}

\author{
Muhammad Iqbal dan Rabendra Yudistira Alamin \\ Departemen Desain Produk, Fakultas Arsitektur, Desain, dan Perencanaan, \\ Institut Teknologi Sepuluh Nopember (ITS) \\ e-mail: rabendrayudistira@gmail.com
}

\begin{abstract}
Abstrak-Sektor pariwisata berperan sebagai penggerak ekonomi Kabupaten Banyuwangi. Hal ini tidak lepas dari upaya promosi yang dilakukan oleh Dinas Kebudayaan dan Pariwisata Banyuwangi. Maka diperlukan perancangan media promosi mengenai destinasi wisata di Banyuwangi yang sejalan dengan visi stakeholder dan kebutuhan target audiens yang disasar, yakni kalangan muda pengguna internet. Metode riset yang dilakukan bersifat kualitatif. Riset yang dilakukan bertujuan untuk mendapatkan konten yang kredibel, serta media yang sesuai. Aspek konten diperoleh melalui riset data primer berdasarkan observasi lapangan serta wawancara, sedangkan aspek media dilakukan melalui studi referensi dan pengujian media. Hasil dari perancangan ini adalah komik berbasis website. Pendekatan humor kekinian dan format naratif komik terbukti mampu membantu menyampaikan konten kepada target audiens secara lebih efektif. Di samping itu, kekurangan media komik dalam menggambarkan kondisi destinasi wisata secara realistis dapat diatasi dengan mengkombinasikan elemen fotografis dalam komik. Penggunaan platform website juga memungkinkan akses yang lebih mudah bagi audiens serta distribusi yang lebih luas.
\end{abstract}

Kata Kunci-Pariwisata Banyuwangi, Media promosi, Komik berbasis web.

\section{PENDAHULUAN}

$\mathrm{S}$ EKTOR pariwisata merupakan salah satu sektor andalan yang dimiliki Indonesia. Selain menjadi salah satu sektor penyedia lapangan pekerjaan terbesar, sektor pariwisata ternyata juga mampu menjadi salah satu kontributor devisa terbesar bagi Negara. Tercatat bahwa sektor pariwisata telah memberikan kontribusi sebesar 4 persen dari keseluruhan PDB nasional, atau sejumlah Rp155 triliun. Sedangkan lapangan kerja yang diciptakan mencapai 11,3 juta.

Salah satu daerah yang menjadi sorotan terkait dengan sektor pariwisata adalah Kabupaten Banyuwangi. Keseriusan upaya pemerintah Kabupaten Banyuwangi terdadap pariwisata salah satunya juga ditandai dari kenaikan pendapatan daerah dari sektor pariwisata di Kabupaten Banyuwangi yang tercatat sejumlah Rp. 40,8 trilliun, dari yang semula sejumlah Rp 22 trilliun pada tahun 2010. Hal - hal yang menunjang kenyamanan calon wisatawan seperti aspek informasi terkait destinasi wisata di Kabupaten tersebut, hingga aspek infrastruktur terus dilakukan pembenahan. Guna menjaga siklus kunjungan wisatawan, baik yang berasal dari dalam negeri maupun luar negeri, pemerintah daerah tersebut menyelenggarakan serangkaian event dalam satu tahun penuh. Total terdapat 34 event dalam berbagai skala dan bidang yang diselenggarakan di berbagai tempat di Banyuwangi. Hal ini juga terkait prioritas pengembangan pariwisata di Banyuwangi yang berusaha untuk tidak mengesankan keterpusatan pada wilayah perkotaan saja.

Upaya yang dilakukan oleh pemerintah Kabupaten Banyuwangi dan segenap pihak yang terlibat dalam pengembangan sektor pariwisata di Kabupaten Banyuwangi ini membuahkan hasil yang tidak mengecewakan. Terbukti bahwa kemudian Kabupaten Banyuwangi lantas mendapatkan apresiasi positif yang di antaranya adalah "UNWTO Awards for Excellence and Innovation in Tourism" untuk kategori "Inovasi Kebijakan Publik dan Tata Kelola".

Upaya lebih lanjut juga dilakukan terkait strategi promosi pariwisata Kabupaten Banyuwangi yang salah satunya menyasar segmentasi netizen. Dinas Kebudayaan dan Pariwisata Kabupaten Banyuwangi memanfaatkan berbagai media berbasis internet seperti aplikasi, website, dan media sosial dengan konten/kiriman yang saling - silang serta membantu mempublikasikan konten website. Strategi promosi tidak langsung melalui media internet juga dilakukan dengan memanfaatkan ketenaran figur publik yang menggunakan media sosial dengan cara endorsing.

Terkait tren penggunaan internet, salah satu konten internet yang turut mengalami kenaikan jumlah pengguna adalah komik online. Kemudahan publikasi komik melalui media online membuat komikus dari beragam latar belakang berlomba mempublikasikan karya mereka baik melalui akun pribadi maupun web khusus komik. Salah satu web penyedia komik berbasis online, 'webtoon', bahkan sudah mencapai angka pembaca 6,5 juta orang sejak didirikan pada tahun 2004.

Beragam materi dalam berbagai genre ditawarkan oleh komikus - komikus yang mengunggah karya mereka pada media online. Mulai dari kisah pribadi terkait kehidupan sehari - hari, kritik sosial, edukasi, bahkan untuk kepentingan propaganda politik atau yang murni fiksi sama sekali (komik seni). Beberapa komikus yang mengunggah karyanya di internet sehingga dapat dibaca secara gratis oleh pengguna internet, bahkan dengan berani membuat komik mereka sebagai media promosi bagi produk atau jasa tertentu atas pertimbangan jumlah pembaca mereka yang tinggi. Selain itu, komik (yang dipublikasikan melalui media sosial) dianggap lebih mampu menjadi media promosi yang interaktif karena sifat responsnya yang langsung dengan audiens dan bersifat dua arah jika dibandingkan dengan iklan pada media lain.

Kaitannya dengan fenomena yang terjadi di Kabupaten Banyuwangi sebagaimana tersebut di atas, maka perlu diusulkan perancangan media yang mengangkat tentang 
pariwisata Banyuwangi dengan pendekatan persuasif menggunakan media berupa komik yang interaktif. Media komik dipilih atas pertimbangan - pertimbangan seperti kemampuannya dalam menyampaikan konten dengan lebih menarik sekaligus mempersingkat bahasa tulis, sekaligus mampu merekonstruksi cerita dengan bahasa yang lebih ilustratif dan mudah untuk diwujudkan jika dibandingkan dengan video maupun tulisan panjang.

Komik yang dirancang tersebut nantinya akan dipublikasikan melalui media internet sebagai bagian dari website pariwisata resmi pemerintah Kabupaten Banyuwangi dan aplikasi pariwisata 'Banyuwangi in Your Hand', dan juga mengoptimalkan fitur media sosial untuk membantu memperbaharui kabar terbaru mengenai cerita dalam komik kepada khalayak.

A. Identifikasi Masalah

1) Pemerintah Kabupaten Banyuwangi mempunyai visi tentang pengembangan potensi pariwisata serta promosi destinasi pariwisata tersebut.

2) Perlunya memaksimalkan potensi media berdasarkan latar belakang dan minat target audiens untuk membangun sebuah komunikasi yang menarik dengan informasi yang kredibel.

\section{B. Rumusan Masalah}

Bagaimana merancang sebuah komik berbasis website yang mampu menyediakan informasi bagi masyarakat tentang destinasi pariwisata di Kabupaten Banyuwangi melalui informasi yang kredibel?

\section{Batasan Masalah}

1) Konten yang dipromosikan mencakup tiga kawasan destinasi wisata : Taman Nasional Alas Purwo, Taman Nasional Meru Betiri, Kawasan Cagar Alam Kawah Ijen.

2) Media yang dirancang penulis berupa komik yang dipublikasikan melalui media website.

\section{Tujuan}

1) Sebagai media informasi bagi calon wisatawan yang membutuhkan wawasan dalam format narasi.

2) Sebagai media edukasi mengenai aspek budaya dan sejarah yang terjadi di destinasi wisata terkait.

\section{STUDI ACUAN}

\section{A. Landasan Teori}

1) Komunikasi Pemasaran

Beberapa ahli berpendapat bahwa komunikasi pemasaran adalah adalah sarana di mana perusahaan berusaha menginformasikan, membujuk, dan mengingatkan konsumen -secara langsung maupun tidak langsung- tentang produk dan merek yang dijual. Intinya, komunikasi pemasaran merepresentasikan "suara" perusahaan dan mereknya serta merupakan sarana di mana perusahaan dapat membuat dialog dan membangun hubungan dengan konsumen [1].

2) Membangun website interaktif

Website interaktif dapat dipahami sebagai perancangan website yang memungkinkan pengguna untuk terikat secara aktif melalui berbagai fitur yang ada di dalamnya. Fitur - fitur tersebut meliputi fitur yang berkaitan dengan kenyamanan mengakses konten, kecepatan terpenuhinya kebutuhan pengguna, hingga pengalaman baru yang tidak ditemukan pada website dengan konten sejenis.

3) Komik sebagai media komunikasi

Cendekiwian Marshall McLuhan, dalam bukunya "Understanding media : The Extensions of Man" (1964) menggolongkan media salah satunya berdasarkan derajat partitipasi audiens menjadi kategori "Hot" dan "Cool". Media seperti film dikategorikan "Hot" karena aktif memberikan pesan dalam visual kualitas, yang oelh karena itu justru mengurangi partisipasi audiens. Sementara media "Cool", termasuk di antaranya komik, menuntut audiensnya untuk terlibat lebih jauh dalam komunikasi untuk melengkapi pesan, yang oleh karena itu, menurut McLuhan, justru membantu keterlibatan audiens dengan media tersebut (dan pesan yang disampaikan). Komikus Scott McCloud merumuskan dasar dasar mengenai teknik bercerita melalui komik yang efektif, meliputi pemilihan alur, bingkai, citra, kombinasi kata, dan alur [2].

\section{4) Teknik Komposisi Fotografi}

Elemen fotografi digunakan untuk mengatasi kekurangan media komik dalam menjelaskan kondisi tempat kejadian secara riil. Fotografi diambil berdasarkan teknik - teknik tertentu yang digunakan untuk menyampaikan gagasan yang berbeda - beda agar lebih efektif.

\section{B. Studi Eksisting}

1) 'Tiga Manula Jalan - jalan ke Singapura Extended'

Objek studi eksisting yang digunakan dalam mengkaji konten berupa komik cetak yang mengangkat konten pariwisata dengan pendekatan humor, serta pengembangan karakter dengan peran - peran spesifik.

2) Travel Series Jalan - jalan Men

Penggunaan gaya bahasa dalam media ini sesuai dengan gaya bahasa dalam percakapan target audiens yang disasar, sehingga efektif dalam menyampaikan konten - konten berupa destinasi wisata yang dipilih.

3) Komik Wonderful Kawah Ijen

Media ini mengangkat konten yang beririsan dengan yang telah diusulkan di atas. Teknik penceritaan dalam media sesuai sebagai acuan untuk mengembangkan komik dengan lebih baik.

\section{METODOLOGI PERANCANGAN}

\section{A. Fenomenologi}

Langkah ini dijalankan guna menemukan latar belakang mengapa judul perancangan ini perlu untuk dilaksanakan. Studi ini mengkaji sumber - sumber data sekunder dari media cetak maupun elektronik.

\section{B. Studi Literatur}

Studi mengenai literatur dilakukan untuk menggali mengenai tinjauan para ahli mengenai media yang hendak dirancang. Studi literatur meliputi teori - teori terkait dengan teknik komunikasi untuk tujuan pemasaran, teknik pengembangan website interaktif, teknik komunikasi melalui komik, serta teknik komposisi fotografi sebagai pelengkap media komik. 


\section{Observasi}

Lokasi : Taman Nasional Meru Betiri, Taman Nasional Alas Purwo, Kawasan Cagar Alam Kawah Ijen

Perihal : Pemetaan potensi destinasi wisata, pengumpulan aset foto.

\section{Wawancara}

Lokasi : Kantor Dinas Kebudayaan dan Pariwisata Kabupaten Banyuwangi

Sasaran : Bagian pemasaran Dinas Kebudayaan dan Pariwisata Kabupaten Banyuwangi

Perihal : Visi dan stratedi promosi pariwisata Kabupaten Banyuwangi.

\section{KONSEP DESAIN}

\section{A. Konsep Luaran}

Hasil riset menghasilkan konsep luaran berupa serangkaian cerita komik yang menceritakan perjalanan karakter di Taman Nasional Alas Purwo, Taman Nasional Meru Betiri, serta Kawasan Cagar Alam Kawah Ijen.

\section{B. Spesifikasi Teknis}

Berdasarkan pengamatan dan perbandingan terhadap objek eksisting yang sejenis, komik yang dipublikasikan melalui media web ini ditampilkan dalam format memanjang dengan dimensi lebar 800 pixel dan panjang bervariasi untuk masing masing episode, dan dalam tampilan full color dengan resolusi 72 dpi. Website yang dirancang dapat diakses melalui PC maupun mobile.

\section{Karakter}

Karakter dalam komik dirancang mewakili masing - masing motivasi target audiens dalam melakukan perjalanan wisata. Desain karakter meliputi tiga karakter utama wanita, serta dua karakter pendukung dengan latar belakang laki - laki. Desain karakter juga dirancang berdasarkan peran dalam cerita, yakni meliputi peran utama yang membawakan cerita, peran informasi, serta peran tambahan seperti pelontar jokes. Desain karakter dalam komik ditampilkan melalui teknik ilustrasi.

\section{Latar Cerita}

Latar tempat cerita (environment) ditampilkan melalui teknik fotografi yang diambil pada masing - masing destinasi wisata, serta latar perjalanan yang dilalui untuk menuju masing - masing destinasi wisata.

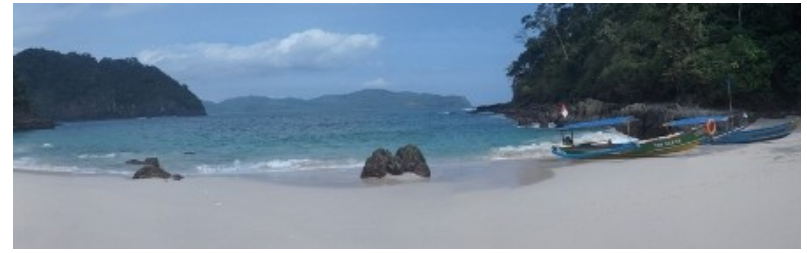

Gambar 1. Stok fotografi latar cerita.

(Sumber: Iqbal, 2017)

\section{E. Narasi dan Storyboard}

Penyusunan cerita dibuat berdasarkan pemetaan potensi destinasi wisata pada masing - masing tujuan wisata. Alur cerita juga disusun berdasarkan alur kegiatan serta letak destinasi wisata yang dituju sehingga dapat menjadi panduan perjalanan yang realistis. Pemetaan alur kegiatan tersebut lalu dikembangkan ke dalam plot cerita.

Tabel 1.

Tema dari BSE yang dapat digunakan sebagai dasar tema cerita

\begin{tabular}{|c|c|c|}
\hline Episode & Konten & Rincian \\
\hline 1 & Prolog & $\begin{array}{l}\text { Pengenalan tokoh utama } \\
\text { Motivasi berwisata }\end{array}$ \\
\hline 2 & $\begin{array}{l}\text { Kedatangan di } \\
\text { Banyuwangi }\end{array}$ & $\begin{array}{l}\text { Pertemuan tokoh dan rencana } \\
\text { perjalanan } \\
\text { Pengamatan satwa TN Alas } \\
\text { Purwo }\end{array}$ \\
\hline 3 & $\begin{array}{l}\text { Eksplorasi TN Alas } \\
\text { Purwo }\end{array}$ & $\begin{array}{l}\text { Penelusuran Goa Istana } \\
\text { Perjalanan menuju Pantai } \\
\text { Plengkung }\end{array}$ \\
\hline 4 & Pantai Plengkung & $\begin{array}{l}\text { Aktivitas di Pantai Plengkung } \\
\text { (Yoga, selancar, memancing, } \\
\text { makan bersama) } \\
\text { Perjalanan kembali dari Pantai } \\
\text { Plengkung }\end{array}$ \\
\hline 5 & Ekowisata Bedul & $\begin{array}{l}\text { Aktivitas di ekowisata mangrove } \\
\text { Blok Bedul (penelusuran muara, } \\
\text { wisata kuliner) } \\
\text { Pesiapan dan perjalanan menuju } \\
\text { TN Meru Betiri }\end{array}$ \\
\hline 6 & $\begin{array}{l}\text { Eksplorasi TN } \\
\text { Meru Betiri }\end{array}$ & $\begin{array}{l}\text { Persiapan kemah, pengamatan } \\
\text { penyu, pelepasan tukik. }\end{array}$ \\
\hline 7 & $\begin{array}{l}\text { Wisata pantai Teluk } \\
\text { Ijo dan Pulau } \\
\text { Merah }\end{array}$ & $\begin{array}{l}\text { Aktivitas di Teluk Ijo dengan dua } \\
\text { opsi jalur. } \\
\text { Belajar dan praktik selancar } \\
\text { Perjalanan menuju Gunung Ijen }\end{array}$ \\
\hline 8 & $\begin{array}{l}\text { Perjalanan menuju } \\
\text { Kawah Ijen }\end{array}$ & $\begin{array}{l}\text { Permasalahan di perjalanan } \\
\text { Pendakian menuju Kawah Ijen } \\
\text { Masing - masing tokoh }\end{array}$ \\
\hline 9 & $\begin{array}{l}\text { Perjalanan turun } \\
\text { dari Kawah Ijen }\end{array}$ & $\begin{array}{l}\text { menceritakan kembali } \\
\text { pengalaman perjalanan melalui } \\
\text { puisi. }\end{array}$ \\
\hline 10 & Epilog & $\begin{array}{l}\text { Pertemuan dengan keluarga salah } \\
\text { satu tokoh utama } \\
\text { Pengamatan budaya Suku Osing }\end{array}$ \\
\hline
\end{tabular}

Sumber: Iqbal, 2016

Narasi kemudian disusun dalam adegan dan dibuat dalam bentuk sketsa di atas kertas dengan panduan aset fotografi latar seperti yang terlihat pada (2).

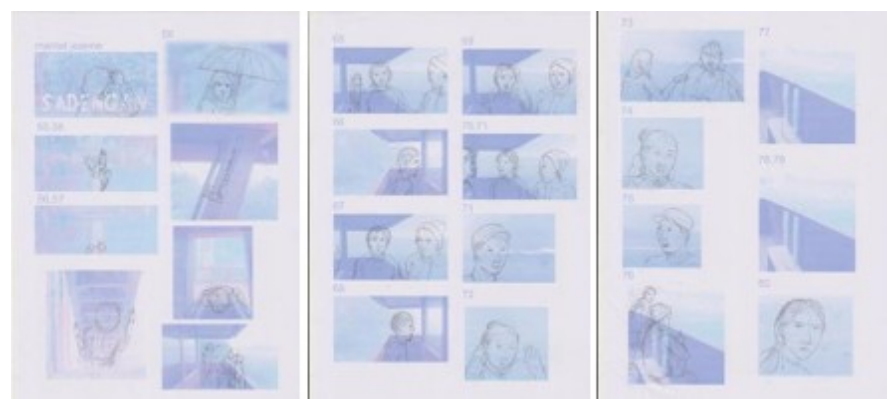

Gambar 2. Sketsa halaman

Sumber: Iqbal, 2017

\section{G. Desain Antarmuka}

1) Tampilan Komik

Gambar (3) merupakan Tampilan dummy halaman komik yang dirancang sebagai contoh untuk diujikan kepada target audiens. Komik episode pertama ditampilkan khusus menggunakan ilustrasi secara keseluruhan, sedangkan penggunaan kombinasi fotografi digunakan pada episode 
dengan latar cerita di tempat wisata, yakni episode dua dan seterusnya.

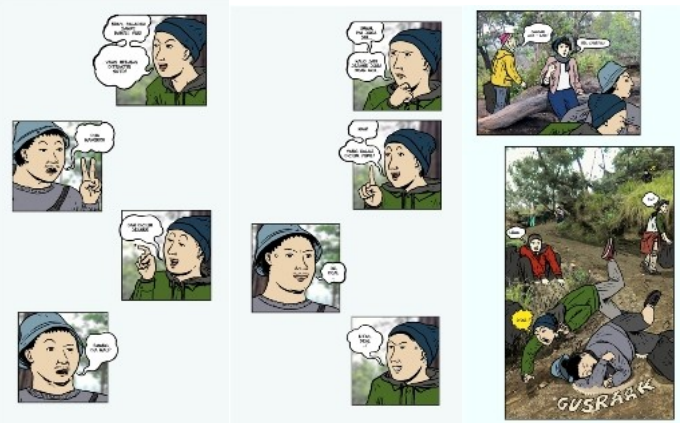

Gambar 3. Hasil rancangan dummy.

Sumber: Iqbal, 2016

\section{2) Tampilan Website}

Perancangan website mengacu pada orientasi desain yang fokus pada tampilan konten komik serta kemudahan akses bagi pengguna. Fitur - fitur interaktif diterapkan dengan tidak mengganggu tampilan komik, serta menunjang pengalaman membaca komik yang unik melalui website.
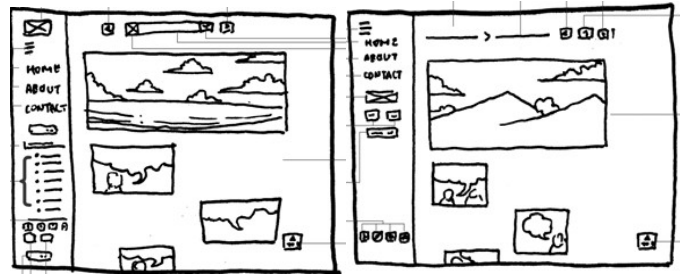

Gambar 4. Sketsa layout halaman website.

Sumber: Iqbal, 2016

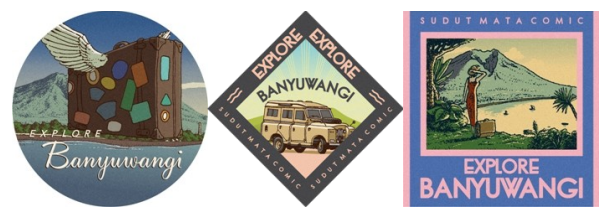

Gambar 5. Alternatif desain logo komik.

Sumber: Iqbal, 2017

\section{F. Konsep Bisnis dan Pengembangan}

1) Media Pendukung

Komik web promosi pariwisata Kabupaten Banyuwangi ini didistribusikan melalui media website yang dirancang khusus. Untuk membantu publikasi, dibuat pula akun - akun media sosial untuk mempublikasikan info mengenai episode terbaru, serta untuk membangun komunitas pembaca.

2) Aspek Keberlanjutan

Pengembangan dalam aspek konten sangat dimungkinkan mengingat potensi dari teknik penceritaan melalui komik yang luas. Selain itu, aspek keberlanjutan terkait pengerjaan dan publikasi komik ditunjang oleh pendanaan dari pihak - pihak yang potensial seperti pemerintah, badan usaha swasta yang berkaitan dengan pariwisata (agen wisata, tiket, dan hotel), serta tawaran iklan yang menyasar target market yang sesuai dengan latar belakang pembaca komik yang "Explore Banyuwangi”.

\section{PEMBAHASAN DESAIN}

Hasil desain adalah berupa konten narasi, aset visual karakter, latar dan elemen antarmuka yang diimplementasikan pada website "explore Banyuwangi".

\section{A. Hasil Akhir Desain Karakter}

Masing-masing karakter yang digambarkan pada (9) merepresentasikan etnis, motivasi berwisata, dan peran dalam membawakan cerita dalam komik.
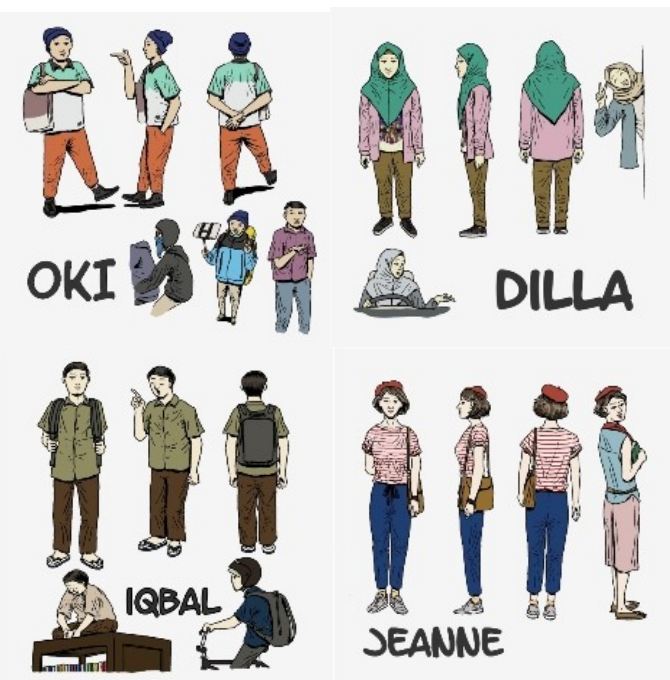

Gambar 6. Hasil akhir desain karakter Sumber: Iqbal, 2016

\section{B. Hasil Akhir Latar Cerita (Environment)}

Fotografi untuk keperluan latar cerita ditampilkan dalam tema warna natural dengan penyesuaian dari hasil fotografi asli. Gambar (7) merupakan tampilan latar cerita.

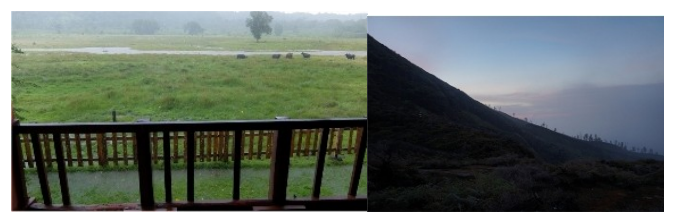

Gambar 7. Hasil akhir fotografi latar Sumber: Iqbal, 2017

\section{Hasil Akhir Layout Halaman Komik}

Gambar (8) merupakan hasil ilustrasi adegan yang diperankan karakter, yang diimplementasikan dalam fotografi latar disertai dialog sesuai dengan storyline.
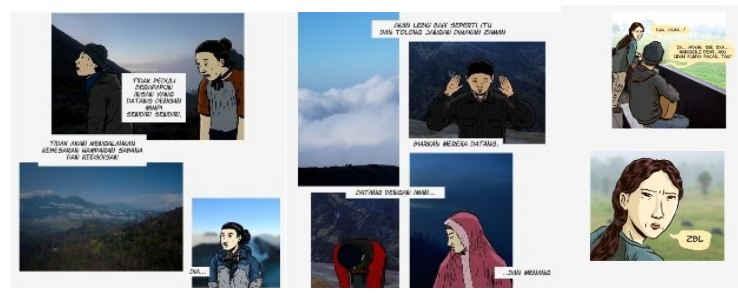

Gambar 12. Hasil akhir layout halaman komik Sumber: Iqbal, 2018 


\section{Hasil Akhir Media Publikasi Pendukung}

Media publikasi pendukung (9) menggunakan elemen visual utama preview dari episode yang akan dipublikasikan dan diunggah melalui akun media sosial.

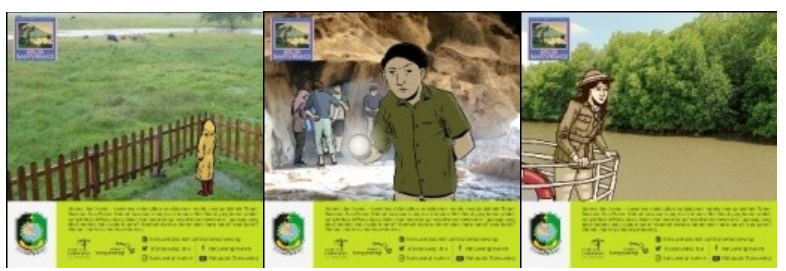

Gambar 9. Hasil media publikasi pendukung Sumber: Iqbal, 2018

\section{E. Implementasi}

Halaman - halaman komik kemudian diemplementasikan dalam website. Gambar (10) menampilkan implementasi komik dalam website.
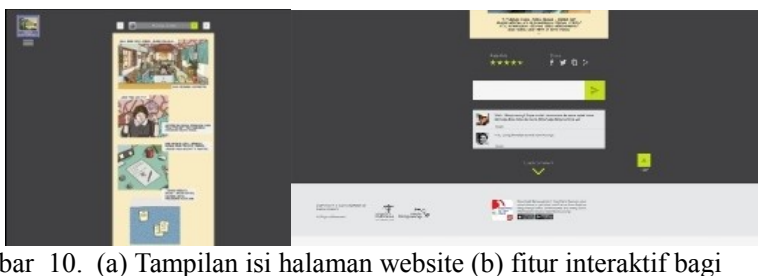

Gambar 10. (a) Tampilan isi halaman website (b) fitur interaktif bagi pembaca.

(Sumber: Iqbal, 2018)

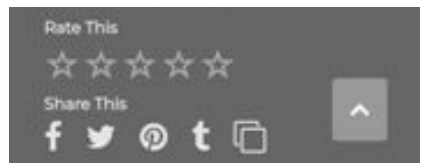

Gambar 11. Fitur share dan rate.

(Sumber: Iqbal, 2018)

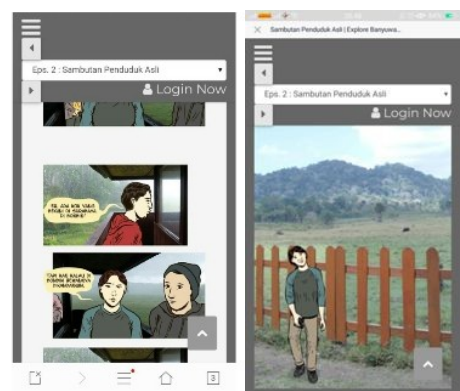

Gambar 12. (a) Tampilan halaman komik dengan kombinasi fotografi (b) Tampilan panel panorama.

(Sumber: Iqbal, 2018)

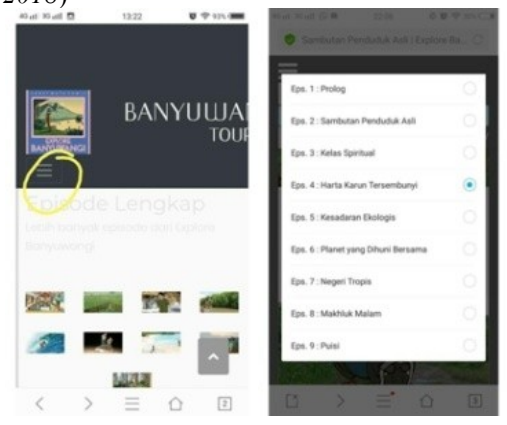

Gambar 13. (a) Tampilan halaman beranda mobile (b). Daftar episode komik (Sumber: Iqbal, 2018)

\section{KESIMPULAN}

Perancangan media komik yang dipublikasikan melalui website dapat menjadi alternatif media promosi alternatif selain langkah promosi yang sudah dilaksanakan stakeholder. Penggunaan media komik yang dipublikasikan melalui website dapat memberikan pengalaman baru bagi target audiens dalam menerima informasi mengenai destinasi wisata di Kabupaten Banyuwangi karena memungkinkan penyajian materi dalam bentuk yang interaktif dan mudah untuk diakses. Konten cerita penjelajahan dengan pendekatan humor yang diangkat dalam komik "Explore Banyuwangi" berpeluang untuk terus dikembangkan, baik dari aspek kontendan inovasi media. Ke depannya, perancangan ini dapat dikembangkan dengan menggali konten mengenai destinasi wisata lain di Banyuwangi, seperti wisata budaya di kampung - kampung adat di Banyuwangi, serta eksplorasi destinasi wisata berbasis ekologi lain seperti perkebunan dan kawasan konservasi. Perlu sumber daya manusia yang cukup agar dapat perancangan konten serta pengelolaan media dapat berlangsung dengan baik. Diperlukan pula dukungan dari berbagai pihak terkait aspek legalitas dan pendanaan agar proses pengembangan konten dan media dapat berlangsung dengan baik dan berkelanjutan.

\section{DAFTAR PUSTAKA}

[1] P. Kotler and K. L. Keller, Manajemen Pemasaran. Jakarta: Erlangga, 2009.

[2] S. McCloud, Membuat Komik. Jakarta: Gramedia Pustaka Utama, 2008. 